\title{
A NEW SPECIES OF TERRESTRIAL PLANARIAN (PLATYHELMINTHES: TRICLADIDA: TERRICOLA) FROM SOUTH BRAZIL
}

\author{
CARBAYO, F. and LEAL-ZANCHET, A. M. \\ Instituto de Pesquisas de Planárias, IPP, Centro de Ciências da Saúde, Unisinos, Av. Unisinos, 950, \\ São Leopoldo, RS, CEP 93022-000, Brazil \\ Correspondence to: Ana Maria Leal-Zanchet, Instituto de Pesquisas de Planárias, IPP, Centro de Ciências da \\ Saúde, Unisinos, Av. Unisinos, 950, São Leopoldo, RS, CEP 93022-000, Brazil, e-mail: ipp@ bios.unisinos.br \\ Received May 18, 2000 - Accepted August 7, 2000 - Distributed August 31, 2001
}

(With 17 figures)

\begin{abstract}
Geoplana josefi sp. nov. of South Brazil is described herein. The species shows etary polymorphism. Neither youngs nor adults show the characteristic colour pattern of the mature worms. The species has a multilayered lining in the female atrium. The allopatric G. trigueira, which does not have such a lining, is similar externally and internally with adults of $G$. josefi, its seminal vesicle, however, being unpaired.
\end{abstract}

Key words: Geoplaninae, Geoplana, taxonomy, morphology.

\section{RESUMO}

\section{Uma nova espécie de planária terrestre (Platyhelminthes: Tricladida: Terricola)} do sul do Brasil

Descreve-se Geoplana josefi sp. nov., do sul do Brasil. A espécie apresenta polimorfismo etário. Os indivíduos jovens e adultos apresentam um padrão de coloração distinto do dos indivíduos maduros. A espécie possui um epitélio de revestimento pluriestratificado no átrio feminino. A espécie alopátrica G. trigueira apresenta semelhanças em sua morfologia externa e interna com a espécie aqui descrita, porém, não possui esse tipo de revestimento e sua vesícula seminal é ímpar.

Palavras-chave: Geoplaninae, Geoplana, taxonomia, morfologia.

\section{INTRODUCTION}

The fauna of the known geoplanids of the State of Rio Grande do Sul, South Brazil, consists of 15 species (Graff, 1899; Froehlich, 1959). Recently two new species (Leal-Zanchet \& Carbayo, 2001) from the national forest of São Francisco de Paula, which is also the type locality of Geoplana josefi, were described.

\section{MATERIAL AND METHODS}

The animals were collected in the national forest of São Francisco de Paula, State of Rio Grande do Sul, South Brazil. This forest is located in the district of Rincão dos Kroeff, between $29^{\circ} 23^{\prime}$ - $29^{\circ} 27^{\prime} \mathrm{S}$, and $50^{\circ} 23^{\prime}-50^{\circ} 25^{\prime} \mathrm{W}$, and covers an area of $\sim 1,600$ ha, at an altitude of $\sim 930 \mathrm{~m}$.

In the laboratory, the size was measured, and the external morphology and colour pattern were observed, all from live and fixed animals. They were killed using boiling water and fixed with neutral formaldehyde or FAA (Romeis, 1989). Tissue blocks were dehydrated in ascending series of ethyl alcohol, treated with isopropyl alcohol and embedded in Paraplast. Sagittal or horizontal 6 to $12 \mu \mathrm{m}$ serial sections of either the anterior region, the pharynx, or the copulatory apparatus, besides transverse sections (6-10 $\mu$ m thick) of the pre-pharyngeal region, were stained by means of the Mallory/Cason and Masson/Goldner (MG) trichrome methods. The ratio of the height of cuta- 
neous musculature to the height of the body (mc:h index) was calculated by the method of Froehlich (1955). The remaining body portions were preserved in $70 \%$ alcohol, and a specimen (paratype 584) was cleared in clove oil to allow for a better visualization of the eyes. The types are deposited in the Zoological Museum of São Paulo (MZUSP) and in the Zoological Museum of the University of the Vale do Rio dos Sinos (MZU). For classification of the secretory cells the Winsor's nomenclature (1998) was adopted.

\section{Taxonomic part}

Geoplanidae Stimpson, 1857

Geoplaninae Stimpson, 1857

Geoplana Stimpson, 1857

Geoplana josefi sp. nov.

Holotype. MZUSP Nr. 353: 31.VII.98 - anterior tip: sagittal sections on 22 slides, ovaries: sagittal sections on 23 slides, anterior testes: sagittal sections on 32 slides, pre-pharyngeal region: transversal sections on 44 slides, pharynx: sagittal sections on 34 slides, copulatory apparatus: sagittal sections on 39 slides.

Type locality. The animals were collected beneath fallen logs and leaf litter in areas of native subtropical forest with and without Araucaria angustifolia (Bert.) Kuntze, and in areas of reforestation with $A$. angustifolia. Two mature specimens were also collected in an area of reforestation with Pinus elliottii Engelm.

Paratypes. MZU Nr. 312B: 08.VI.98 - prepharyngeal region: transversal sections on 35 slides, pharynx: sagittal sections on 59 slides, sopulatory apparatus: sagittal sections on 93 slides; MZUSP Nr. 585B: 11.II.99 - preserved in 70\% alcohol; MZU Nr. 585A: 11.II.99 - copulatory apparatus: horizontal sections on 29 slides; MZU Nr. 563: 14.I.99 - preserved in 70\% alcohol; MZUSP Nr. 347: 31 .VII.98 - pre-pharyngeal region: transversal sections on 9 slides, pharynx: sagittal sections on 44 slides, copulatory apparatus: sagittal sections on 30 slides; MZU Nr. 259: 04.V.98 - anterior tip: transversal sections on 28 slides; MZUSP Nr. 485: 25.II.98 - preserved in 70\% alcohol; MZU Nr. 229: 03.III.98 - pre-pharyngeal region: transversal sections on 13 slides, pharynx: sagittal sections on 23 slides, copulatory apparatus: sagittal sections on 29 slides; MZU Nr. 453: 23.X.98 - pre-pharyngeal region: transversal sections on 13 slides, copulatory apparatus: sagittal sections on 29 slides; MZU Nr. 584: 11.II.99 - in clove oil; MZU Nr. 255: 4.V.98 preserved in 70\% alcohol; MZU Nr. 236: 3.IV.98 preserved in 70\% alcohol; MZUSP Nr. 226: 3.III. 98 - preserved in $70 \%$ alcohol.

Etymology. The specific epithet refers to Prof. Dr. Josef Hauser, founder of the Institute for Planarian Research (Instituto de Pesquisas de Planárias, IPP).

\section{Diagnosis}

Juveniles dorsally cream ground colour with a median stripe and two lateral bands, all of which constituted of a fine dark-brown pigment; anterior tip orange-brown. Mature worms greenish dark-brown, with abundant pigment flecks, without a stripe nor bands; anterior tip dark-brown. Dorsal eyes without light halos; mc:h index, 7\%-11\%; dorsal longitudinal cutaneous musculature thicker near the body margins; glandular margin; cylindrical-type pharynx; esophagus:pharynx ratio, 18\%-29\%; seminal vesicle extrabulbar with paired proximal portions next to the penis bulb; penis papilla with dorsal insertion posteriorly displaced; and female atrium folded, longer than the male one, lined with a multilayered epithelium.

\section{External morphology}

The body has an elongated foliaceous shape (Figs. 1-3), very flat in the largest ones, reaching $130 \mathrm{~mm}$ long and $7 \mathrm{~mm}$ wide (Table 1). Under preserved conditions, the ratio between body height and body width at the pre-pharyngeal region ranges from $15.7 \%$ (paratype $312 \mathrm{~B}$ ) to $20.6 \%$ (paratype 229). The maximal width occurs at the third body quarter, gradually tapering anteriorly and posteriorly. The anterior tip is rounded, the posterior one being obtuse.

The animals show etary polimorphism, but young as well as mature worms exhibit a different coloration from that of the remaining body regions at the anterior one (Figs. 1-3). Alive young specimens dorsally present a cream ground colour. Over this there are a median stripe $(\sim 1 / 9$ of body width) besides two lateral bands ( 1/5 of body width each), all of them consisting of a fine darkbrown pigment. The anterior tip $(\sim 1 / 15$ of body length) is orange-brown and has a brownish rim. The median stripe may not reach this tip. The bands always fade before reaching the tip $(\sim 2 / 15$ of body length), giving to this body region the aspect of a light transversal band. 
Throughout sexual maturation the median stripe becomes broader and the band margins become difuse, especially the external ones towards the posterior tip. Large dark-brown flecks begin behind the anterior tip (1/6 of body length) and are progressively more numerous towards the posterior end.

In completely mature worms, when the pigment flecks are more abundant, the back surface acquires a greenish dark-brown colour. The anterior tip becomes dark-brown and the median stripe as well as the lateral bands, characteristic of the youngs, fade and become hidden by the abundant flecks (Fig. 3).

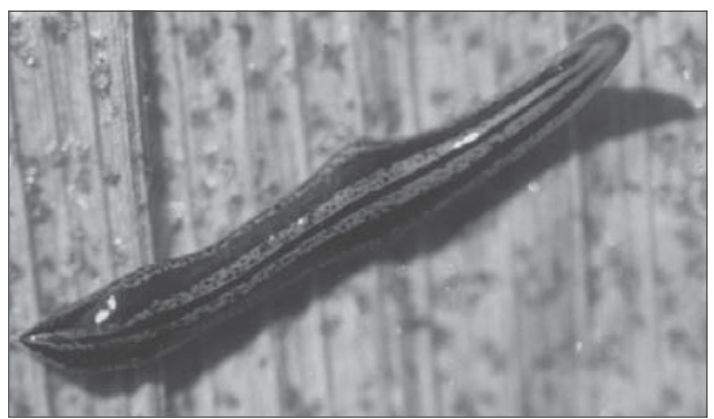

Fig. 1 - Geoplana josefi sp. nov. Dorsal view of a living young specimen. Length $13 \mathrm{~mm}$.

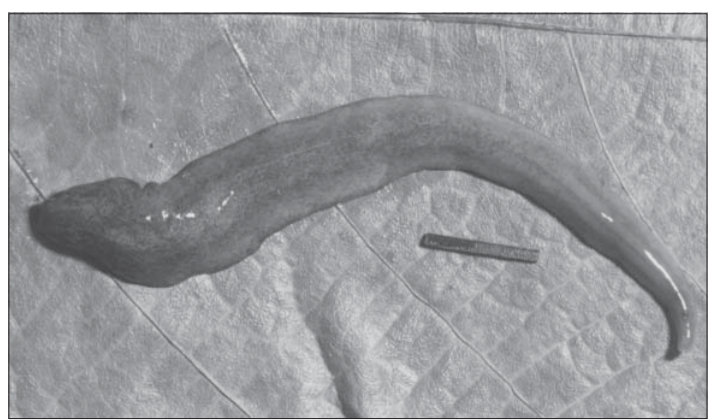

Fig. 2 - Geoplana josefi sp. nov. Dorsal view of a living mature specimen. Scale bar: $10 \mathrm{~mm}$.

The ventral surface of young and mature specimens is greenish gray excepting the anterior tip ( 1/6 of body length), which is orange-brown. Around the mouth there is a whitish, or sometimes orange, coloration. In mature worms, the region around the gonopore is whitish.

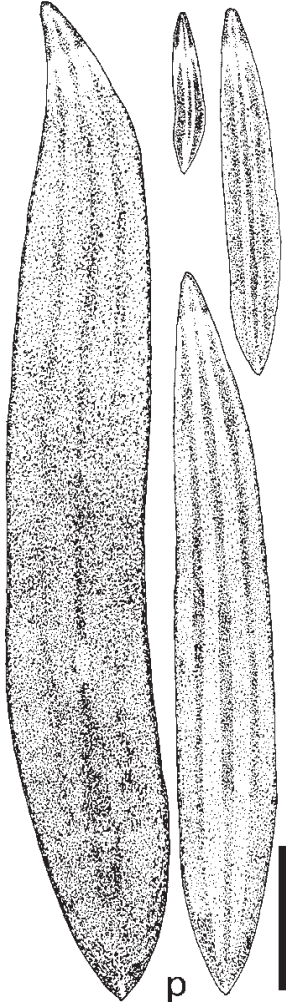

Fig. 3 - Geoplana josefi sp. nov. Dorsal view of preserved paratypes. From the smallest to the largest one: two youngs, an adult and a mature specimen. Scale bar: $10 \mathrm{~mm}$. p = posterior tip.

In preserved worms the coloration weakens, but the median stripe and the lateral bands become sharper.

In the mature paratype 584 there are $~ 1400$ eyes, which are dorsal and have not light halos. They begin in a single row around the anterior tip, gradually spreading onto the dorsal side until reaching $1 / 6$ of body width on either side. This occurs in the region that corresponds to the second and third sixths of body length (Fig. 4), where they are trilobated. Posteriorly to this region they become less numerous, but are present until the posterior tip. The largest eyes are located on the first sixth of the body. These are monolobated and reach $55 \mu \mathrm{m}$ in diameter.

\section{Internal morphology}

The creeping sole reaches the glandular margin (Fig. 5) and extends onto $91 \%-93 \%$ of the body width measured at the prepharyngeal region.

In the anterior third of the body there are the sensory pits in the form of cylindrical invaginations measuring $40 \mu \mathrm{m}$ deep (Fig. 11). 
The cutaneous musculature consists of a subepithelial layer of circular muscles, a diagonal layer composed of two sets of decussate oblique fibres and an inner layer of longitudinal muscle bundles. In the lateral body regions the dorsal longitudinal musculature increases in thickness and number of fibres per bundle (Table 2), so that it becomes of double-thickness, and in some specimens, triplethickness (Figs. 5, 12 and 13). Towards the body margins this musculature gradually weakens.

TABLE 1

Measurements of the type specimens of Geoplana josefi sp. nov. (in mm) arranged from the largest to the smallest length after fixation.

\begin{tabular}{|l|c|c|c|c|c|c|c|c|c|c|c|c|c|c|}
\hline Specimen & $\mathbf{3 1 2 B}$ & $\mathbf{5 8 5 B}$ & $\mathbf{5 8 5 A}$ & $\mathbf{5 6 3}$ & $\mathbf{3 4 7}$ & $\mathbf{2 5 9}$ & holotype & $\mathbf{4 8 5}$ & $\mathbf{2 2 9}$ & $\mathbf{4 5 3}$ & $\mathbf{5 8 4} *$ & $\mathbf{2 5 5}$ & $\mathbf{2 3 6}$ & $\mathbf{2 2 6}$ \\
\hline Length at rest & 70 & 50 & 45 & 50 & 55 & 50 & 50 & 30 & 35 & 45 & 50 & 27 & 13 & 7 \\
\hline Width at rest & 13 & 11 & 9 & 7 & 10 & 10 & 9 & 8 & 6 & 9.5 & 10 & 8 & 4 & 2 \\
\hline $\begin{array}{l}\text { Maximum length in } \\
\text { extension }\end{array}$ & 130 & $?$ & 90 & 95 & 80 & 95 & 102 & 63 & 85 & 85 & $?$ & 66 & 35 & 14 \\
\hline $\begin{array}{l}\text { Maximum width in } \\
\text { extension }\end{array}$ & 7 & $?$ & 6 & 6 & 6 & 7 & 6 & 5 & 5 & 5 & $?$ & 4 & 2.5 & 1.5 \\
\hline $\begin{array}{l}\text { Length after fixation } \\
\text { Width after fixation }\end{array}$ & 11 & 89 & 87.5 & 78 & 77 & 75 & 60 & 52 & 51 & 50 & 35 & 33 & 25 & 12 \\
\hline DM & 61 & 58 & 61 & 52 & 53 & 51 & 43 & 41 & 36 & 37 & 25 & 25.5 & 18 & 10.2 \\
\hline $\begin{array}{l}\text { DM relative to body } \\
\text { length in percent }\end{array}$ & 67.8 & 65.2 & 69.7 & 66.7 & 68.8 & 68 & 71.7 & 78.9 & 70.6 & 74 & 71.4 & 77.3 & 72 & 85.5 \\
\hline DG & 76 & 74 & 73.5 & 63 & 65 & 63 & 52 & 47.5 & 43 & 43 & 31 & 29 & absent & absent \\
\hline $\begin{array}{l}\text { DG relative to body } \\
\text { length in percent }\end{array}$ & 84.4 & 83.1 & 84 & 80.8 & 84.4 & 84 & 86.7 & 91.3 & 84.3 & 86 & 88.6 & 87.9 & - & - \\
\hline
\end{tabular}

Except for the length and width at rest and in extension, all the measurements and ratios were calculated for fixed material.

* The specimen was maintained in clove oil; DM: distance of mouth from anterior end; DG: distance of gonopore from anterior end.

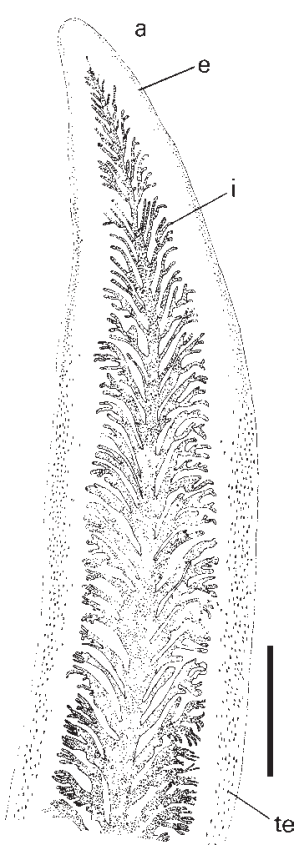

Fig. 4 - Geoplana josefi sp. nov. Intestine and pattern of eyes distributions of a clarified specimen (paratype 584). Scale bar: $5 \mathrm{~mm}$. a = anterior tip; e = one-cup eyes; $\mathrm{i}=$ intestine; te $=$ trilobated eyes.
The mc:h ratio, measured at the median sagittal plane in the pre-pharyngeal region, varies from $7.1 \%$ in the paratype $312 \mathrm{~B}$ to $10.9 \%$ in the paratype 453 (Table 2).

Most mesenchymal muscle fibres are disposed as: oblique fibres in different orientations; dorso-ventral fibres; and transverse fibres dorsally and ventrally to the intestine.

The glandular margin (Fig. 5) is composed of a type of basiphilic granulous secretory cell and three types of acidophilic cells (MG): amorphous xanthophilic, granulous xanthophilic and granulous acidophilic. Basiphilic and acidophilic secretory cells as well as rhabditogen cells open onto the whole epidermal surface, the latter ones being more dispersed ventrally.

The pharynx is cylindrical with the dorsal insertion slightly posterior to the ventral one (Fig. $6)$. It is $\sim 4 \mathrm{~mm}$ long. The esophagus-pharynx ratio varies from $18 \%$ (holotype) to $29 \%$ (paratype 347 ). The mouth lies approximately in the middle of the pharyngeal cavity. This cavity is considerably longer than the pharynx, probably due to pharynx contraction during fixation, and is lined with a non- 
ciliated epithelium. The musculature of the pharyngeal cavity is composed of a thin layer $(6.5 \mu \mathrm{m}$ thick) of oblique fibres. The pharynx has a densely ciliated external epithelium. The external musculature is composed of a thin longitudinal subepithelial layer, under which occurs a circular layer followed by a longitudinal one. Numerous cell necks of granulous pharyngeal glands longitudinally traverse the mesenchyme of the pharynx opening through its distal epithelium. There are three types of such glands: the xanthophilic, the most abundant, besides the acidophilic and basiphilic (Cason). The inner pharyngeal epithelium possesses numerous invaginations. A dense layer of circular muscles $(100-250 \mu \mathrm{m})$ underlies this epithelium. Sparse radial muscle fibres are located in the pharyngeal mesenchyme.

The anterior intestinal branch (Fig. 4) has 95 main diverticles, and each posterior intestinal branch, 17 (paratype 584).

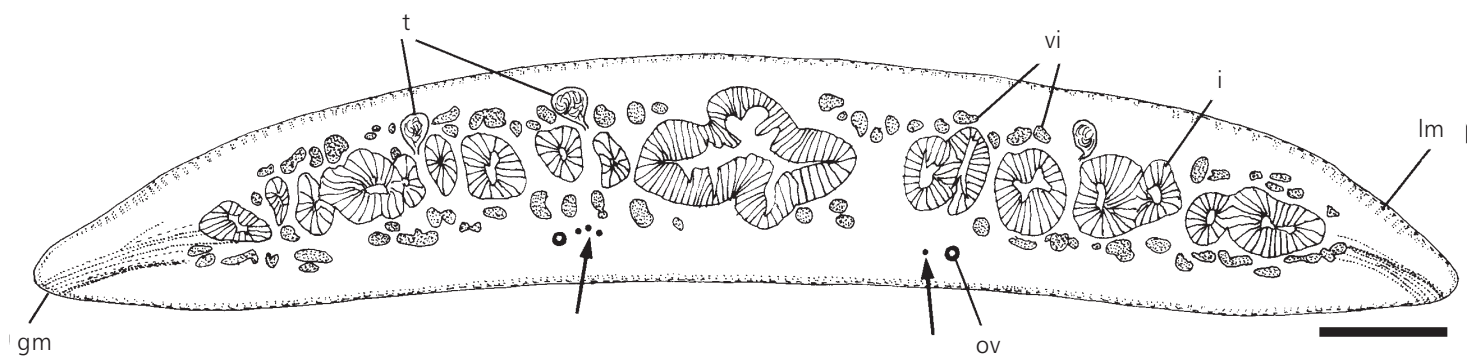

Fig. 5 - Geoplana josefi sp. nov. Diagrammatic transverse section of the pre-pharyngeal region (paratype 312B). Arrows: efferent ductules. Scale bar: $1 \mathrm{~mm}$. $\mathrm{gm}=$ glandular margin; $\mathrm{i}=$ intestine; $1 \mathrm{~m}=$ longitudinal cutaneous muscles; ov $=$ ovovitelline duct; $\mathrm{t}=$ testes; $\mathrm{vi}=$ vitellaria .

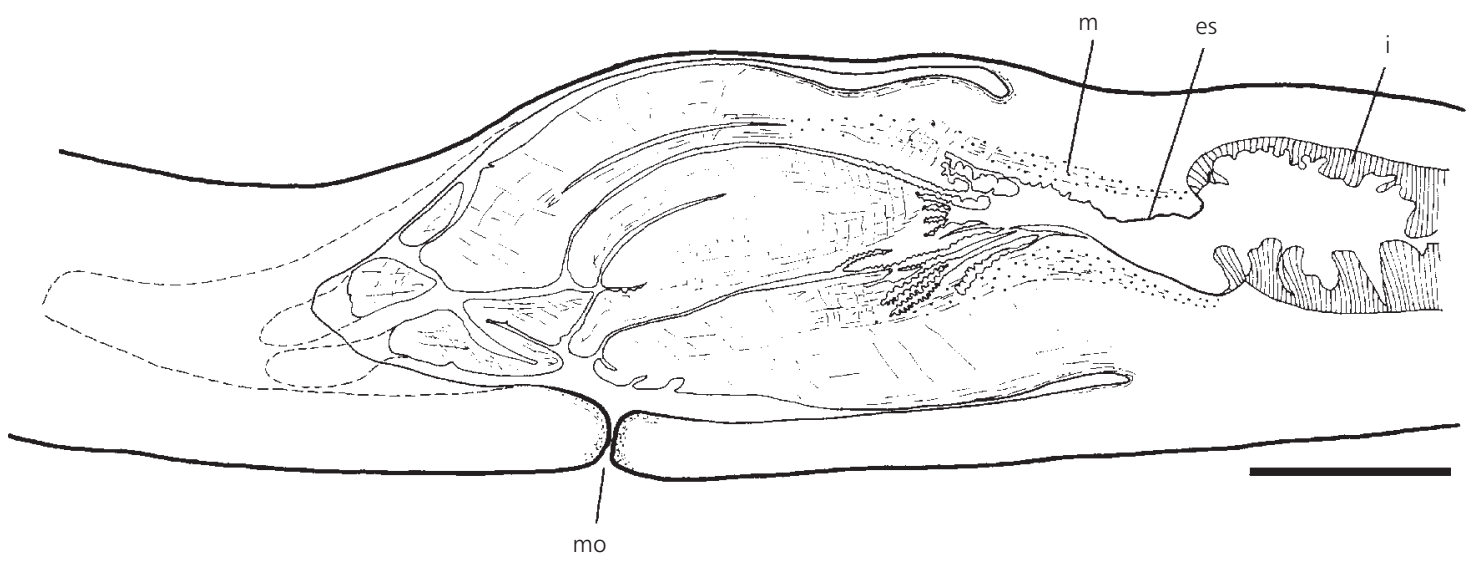

Fig. 6 - Geoplana josefi sp. nov. Sagittal reconstruction of the pharynx (holotype). Scale bar: $1 \mathrm{~mm}$. es = esophagus; $\mathrm{i}=$ intestine; $\mathrm{m}=$ muscles; $\mathrm{mo}=$ mouth.

\section{Reproductive organs}

The testes are pre-pharyngeal, located dorsally to the intestine in two irregular rows on each side of the body (Fig. 5). They begin behind the ovaries aproximately $18 \mathrm{~mm}$ from the anterior tip (nearly $30 \%$ of the body length), and continue to within $38 \mathrm{~mm}$ from the anterior tip (about 63\% of the body length) in the holotype. The efferent ducts are lined with a cubic ciliated epithelium underlain by a circular muscular layer $(4.5 \mu \mathrm{m}$ thick). Their distal portions (Figs. 7-10) expand and form false vesicles. They run upwards to the median sagittal plane, narrow and open into the paired branches of the seminal vesicle.

The seminal vesicle, viewed from above, is Tshaped (Fig. 10). 
TABLE 2

Thickness of cutaneous musculature in the pre-pharyngeal region of Geoplana josefi sp. nov.

\begin{tabular}{|c|c|c|c|c|c|}
\hline Specimen nr. & 312B & 347 & Holotype & 453 & 229 \\
\hline Dorsal circular & $\begin{array}{c}4.3 \\
(7-8)\end{array}$ & $\begin{array}{c}6.5 \\
(5-7)\end{array}$ & $\begin{array}{c}6.5 \\
(5-9)\end{array}$ & $\begin{array}{c}6.5 \\
(3-5)\end{array}$ & $\begin{array}{c}4.3 \\
(3-5)\end{array}$ \\
\hline Dorsal diagonal & $\begin{array}{c}10.8 \\
(5-12)\end{array}$ & $\begin{array}{l}26.1 \\
(7-8)\end{array}$ & $\begin{array}{c}19.5 \\
(6-10)\end{array}$ & $\begin{array}{c}34.7 \\
(6-14)\end{array}$ & $\begin{array}{l}10.8 \\
(6)\end{array}$ \\
\hline Dorsal longitudinal & $\begin{array}{c}43.5 \\
(27-63)\end{array}$ & $\begin{array}{c}47.8 \\
(40-58)\end{array}$ & $\begin{array}{c}30.4 \\
(41-66)\end{array}$ & $\begin{array}{c}58.7 \\
(23-27)\end{array}$ & $\begin{array}{c}26.1 \\
(35-40)\end{array}$ \\
\hline Dorsal total & 58.7 & 80.4 & 56.5 & 100 & 41.3 \\
\hline $\begin{array}{l}\text { Dorsal longitudinal } \\
\text { near the margin }\end{array}$ & $\begin{array}{c}117.4 \\
(75-106)\end{array}$ & $\begin{array}{c}145.6 \\
(76-78)\end{array}$ & $\begin{array}{c}82.6 \\
(46-99)\end{array}$ & $\begin{array}{c}147.8 \\
(52-89)\end{array}$ & $\begin{array}{c}54.3 \\
(46-75)\end{array}$ \\
\hline Ventral circular & $\begin{array}{c}8.7 \\
(6-8)\end{array}$ & $\begin{array}{c}6.5 \\
(7-10)\end{array}$ & $\begin{array}{l}10.8 \\
(7-10)\end{array}$ & $\begin{array}{c}8.7 \\
(5-7)\end{array}$ & $\begin{array}{c}4.3 \\
(4-6)\end{array}$ \\
\hline Ventral diagonal & $\begin{array}{l}21.7 \\
(6-7)\end{array}$ & $\begin{array}{c}26 \\
(7-11)\end{array}$ & $\begin{array}{c}28.3 \\
(9-17)\end{array}$ & $\begin{array}{l}23.9 \\
(6-12)\end{array}$ & $\begin{array}{l}10.8 \\
(6-9)\end{array}$ \\
\hline Ventral longitudinal & $\begin{array}{c}39.1 \\
(30-38)\end{array}$ & $\begin{array}{c}30.4 \\
(36-66)\end{array}$ & $\begin{array}{c}43.5 \\
(29-51)\end{array}$ & $\begin{array}{c}34.8 \\
(30-34)\end{array}$ & $\begin{array}{c}34.8 \\
(24-36)\end{array}$ \\
\hline Ventral total & 69.5 & 73.9 & 82.6 & 67.4 & 50 \\
\hline Body height & 1,800 & 1,600 & 1,600 & 1,530 & 1,100 \\
\hline mc:h & $7.1 \%$ & $9.6 \%$ & $8.7 \%$ & $10.9 \%$ & $8.3 \%$ \\
\hline
\end{tabular}

The thickness is given in $\mu \mathrm{m}$ (each first line) and in number of fibres by bundle with the lowest and highest numbers of muscle fibres (in parenthesis). The body height is given in $\mu \mathrm{m}$.

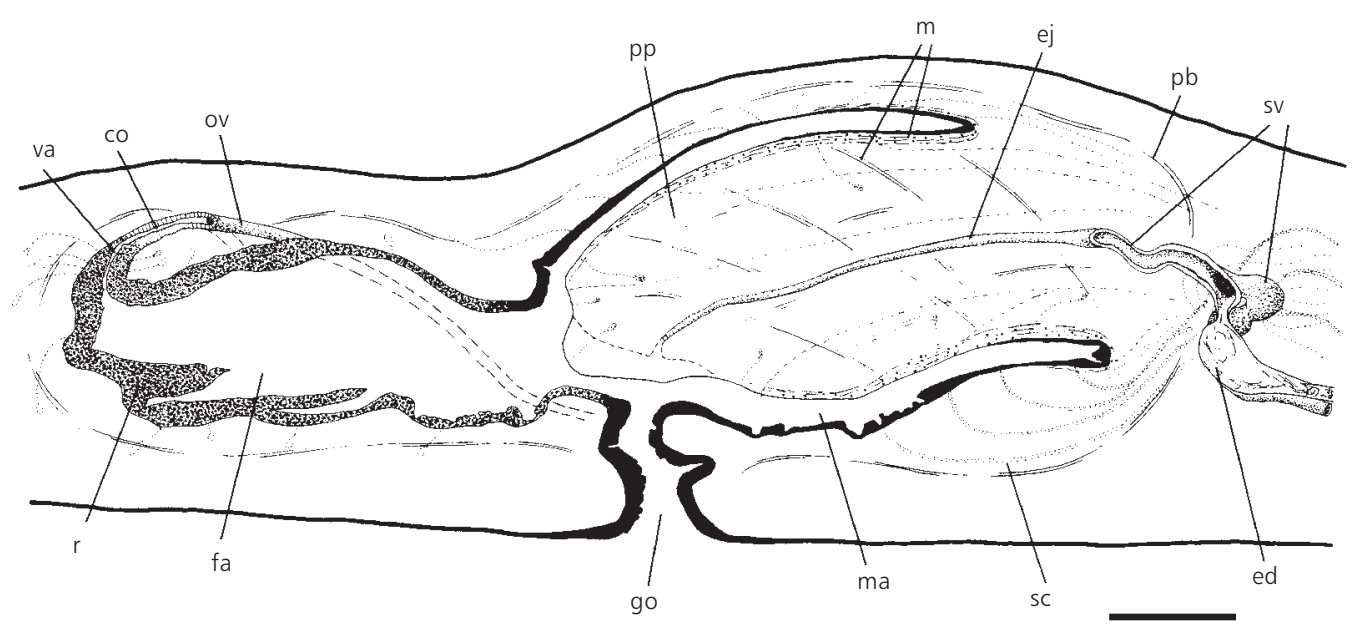

Fig. 7 - Geoplana josefi sp. nov. Sagittal reconstruction of the copulatory apparatus (holotype). Scale bar: $0.5 \mathrm{~mm}$. co = common glandular ovovitelline duct; ed = efferent duct; ej = ejaculatory duct; fa = female atrium; go = gonopore; $\mathrm{m}=$ muscles; $\mathrm{ma}=$ male atrium; ov = ovovitelline duct; $\mathrm{pb}=$ penis bulb; $\mathrm{pp}=$ penis papilla; $\mathrm{r}=$ multilayered lining of the female atrium; $\mathrm{sc}=$ secretory cells; $\mathrm{sv}=$ seminal vesicle; $\mathrm{va}=$ vagina .

It is constituted by two short paired extrabulbar branches and an unpaired partially intrabulbar branch.

The extrabulbar portions of the seminal vesicle are located next to the penis bulb. In an incompletely mature specimen (paratype 229), the paired branches are minimally developed.
The intrabulbar portion is slightly sinuous and progressively narrowed (Figs. 7-10), giving rise to the ejaculatory duct inside the penis papilla.

The seminal vesicle is lined by a ciliated collumnar epithelium. 
The extrabulbar portion receives the secretion of two types of secretory cells, an acidophilic densely granulous type (Fig. 14) and a xanthophilic one (Cason). The intrabulbar portion shows a lower columnar epithelium and receives the secretion of xanthophilic secretory cells (Fig. 15).

The vesicular complex is surrounded by a muscular coat ( $80 \mu \mathrm{m}$ thick), constituted of an inner layer of diagonally crossed fibres and an outer layer of circular ones. The musculature of the intrabulbar portion is thinner.

The penis papilla is oblique, with the dorsal insertion posteriorly displaced (Figs. 7 and 8). In the paratype 453 (Fig. 9), the ventral insertion is dorsally dislocated, it seems caused by contraction during fixation. In some specimens the tip of the papilla, where the ejaculatory duct opens, is locally infolded (Figs. 8 and 9). Numerous necks of four types of secretory cells open through the epithelium of the papilla. Two types, respectively with xanthophilic and acidophilic secretion (Cason, MG), have their cell bodies located externally to the penis bulb. The xanthophilic cell type is the most abundant of the penis glands. A third type presents short necks with acidophilic granular secretion (Cason), its cell bodies being located inside the penis papilla.

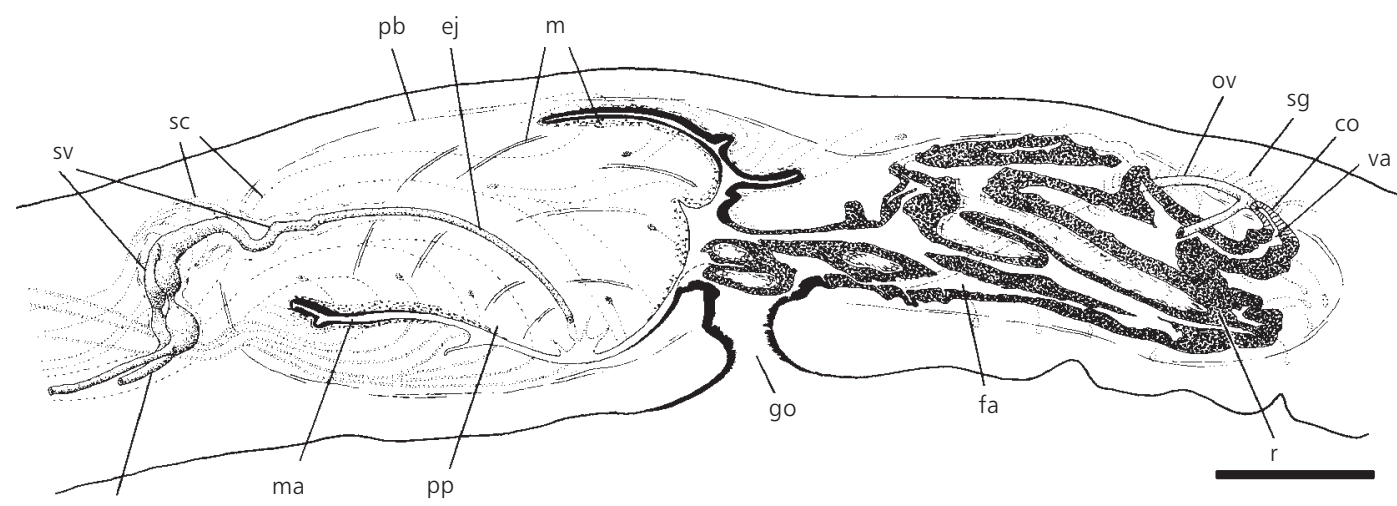

Fig. 8 - Geoplana josefi sp. nov. Sagittal reconstruction of the copulatory apparatus (paratype 312B). Scale bar: $1 \mathrm{~mm}$. co = common glandular ovovitelline duct; ed $=$ efferent duct; ej $=$ ejaculatory duct; fa $=$ female atrium; go $=$ gonopore; $\mathrm{m}=$ muscles; $\mathrm{ma}=$ male atrium; ov $=$ ovovitelline duct $; \mathrm{pb}=$ penis bulb; $\mathrm{pp}=$ penis papilla; $\mathrm{r}=$ multilayered lining of the female atrium; $\mathrm{sc}=$ secretory cells; $\mathrm{sg}=$ shell glands; $\mathrm{sv}=$ seminal vesicle; $\mathrm{va}=$ vagina .

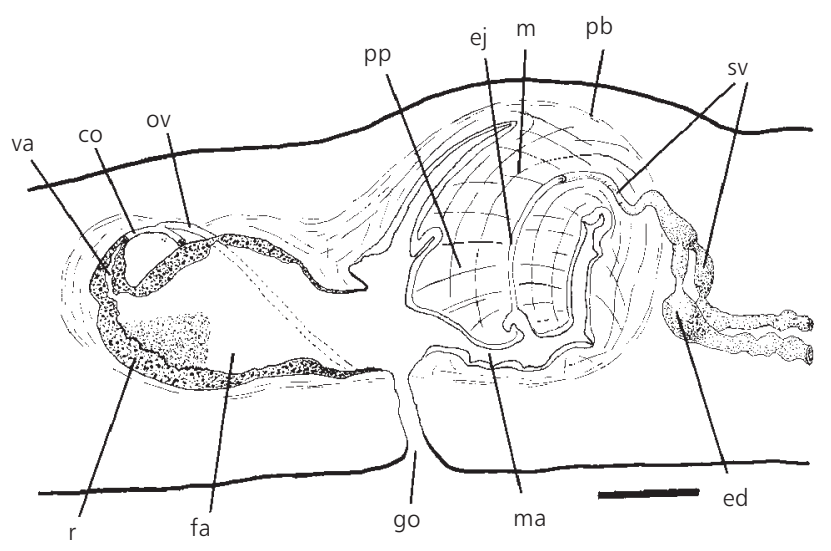

Fig. 9 - Geoplana josefi sp. nov. Sagittal reconstruction of the copulatory apparatus (paratype 453). Scale bar: $0.5 \mathrm{~mm}$. co $=$ common glandular ovovitelline duct; ed $=$ efferent duct; ej $=$ ejaculatory duct $;$ fa $=$ female atrium; go $=$ gonopore; $\mathrm{m}=$ muscles; $\mathrm{ma}=$ male atrium; ov = ovovitelline duct; $\mathrm{pb}=$ penis bulb; $\mathrm{pp}=$ penis papilla $; \mathrm{r}=$ multilayered lining of the female atrium; sv = seminal vesicle; va = vagina . 


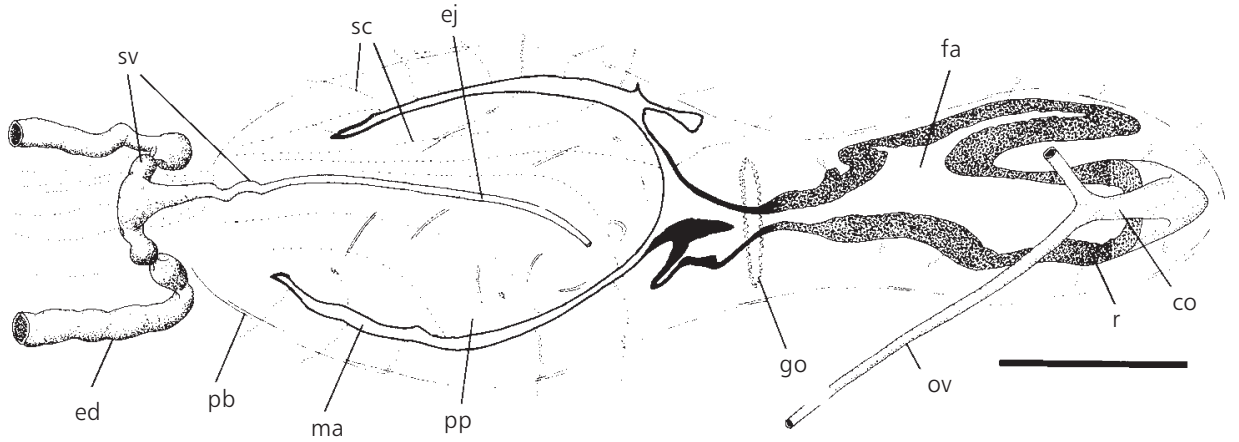

Fig. 10 - Geoplana josefi sp. nov. Horizontal reconstruction of the copulatory apparatus (paratype 585A). Scale bar: $1 \mathrm{~mm}$. co $=$ common glandular ovovitelline duct; ed = efferent duct; ej = ejaculatory duct; fa $=$ female atrium; go = gonopore $; \mathrm{ma}=$ male atrium $; \mathrm{pb}=$ penis bulb; $\mathrm{pp}=$ penis papilla $; \mathrm{r}=$ multilayered lining of the female atrium; $\mathrm{sc}=$ secretory cells; $\mathrm{sv}=$ seminal vesicle $; \mathrm{ov}=$ ovovitelline duct.

A fourth type, less abundant, contains a basiphilic secretion and shows cell bodies located in the mesenchyme of the papilla or in the mesenchyme of the penis bulb.

The muscularis of the penis papilla consists of a $65 \mu \mathrm{m}$ thick subepithelial layer of circular and longitudinal intermixed fibres (Figs. 7 and 8). There are radial and longitudinal muscle fibres in the mesenchyme of the papilla (Fig. 9).

The ejaculatory duct is lined by a ciliated cubic epithelium, through which acidophilic granulous secretory cells open. The musculature is constituted of a circular layer.

The male atrium is almost completely occupied by the penis papilla, that reaches the gonopore. Characteristically, numerous necks of secretory cells open proximally into the ventral half of the atrium (Figs. 7 and 8), the secretion of which having a less defined coloration (orange stained with MG; lilac with Cason). Acidophilic granulous secretory cells (dark red, Cason) open dorsally through the epithelium of the proximal half of the atrium and ventrally near the insertion of the papilla. The atrial musculature $(6.5 \mu \mathrm{m}$ thick $)$ consists of a subepithelial layer of longitudinal fibres followed by a circular one.

The ovaries $(\sim 1 \times 0.3 \mathrm{~mm})$ are located ventrally to the intestine, $15 \mathrm{~mm}$ from the anterior tip of the holotype, in a position equivalent to $25 \%$ of the body length. The ovovitelline ducts emerge from the dorsal aspect of the ovaries and run backwards dorsally to the nerve plate. After the gonopore they rise and proceed posteriorly directed to the median sagittal plane. Dorsally to the female atrium they unite and continue backwards as the common glandular ovovitelline duct (Fig. 10). This duct opens into the proximal extremity of the female atrium through a conspicuous vagina, which runs downwards (Figs. 7-9). The distal ascending half of the ovovitelline ducts, as well as the common glandular ovovitelline duct, receive the secretion of the shell glands.

The female atrium is highly folded and has an oval-elongated shape. It is $110 \%-160 \%$ longer than the male atrium.

The vagina and the female atrium are lined with a multilayered non-ciliated epithelium. This epithelium receives three types of secretory cells: the first two types, respectively with xanthophilic and acidophilic secretion, have short cell necks and their bodies underlie the atrial musculature. A third cell type is basiphilic and has its cell bodies posteriorly and dorsally to the atrium. This latter type of secretory cell, abundant in the vagina, becomes less frequent towards the gonopore. The apical epithelial surface of the vagina and of the female atrium shows irregular indentations, some of which being filled with basiphilic and, less frequently, acidophilic secretions of the atrial glands cited above (Figs. 16 and 17). The indentations become less numerous towards the gonopore.

The subepithelial musculature of the female atrium (10-20 $\mu \mathrm{m})$ is constituted of intermixed longitudinal and circular fibres. The overall musculature of the female atrium is poorly developed, and consists of longitudinal fibres under which there are circular ones. 


\section{DISCUSSION}

Ogren \& Kawakatsu (1990) split the genus Geoplana Stimpson 1857, which had already been restricted to species with dorsal testes and neotropical distribution (Froehlich, 1955; Ogren \& Kawakatsu, 1990), into six new genera: Geoplana, Enterosyringa (monotypic), Gigantea, Notogynaphallia, and Pasipha besides the collective group Pseudogeoplana. In addition, these authors proposed two subgenera for the genus Geoplana s.s., Geoplana and Barreirana, based on two characters: body size and the occurrence of transverse colour bands. Considering that the existence of a transverse colour pattern is a variable character in G. josefi, and that the mature animals reach more than $10 \mathrm{~cm}$ in length, $G$. josefi was allocated to the subgenus Geoplana Ogren \& Kawakatsu, 1990.

In the genus Geoplana s.s. there are 21 described species showing a multilayered lining in the female atrium (Table 3 ). G. josefi differs from these species in having a distinctive colour pattern.

Several species with dorsal eyes (Table 3) differ from $G$. josefi in possessing clear halos around the eyes.

The description of $G$. beckeri does not mention clear halos around the eyes, but their distribution is peculiar as they spread onto the back from its very beginning.

TABLE 3

Diagnostic comparation of Geoplana spp. having a multilayered epithelium in the female atrium to Geoplana josefi sp. nov.

\begin{tabular}{|c|c|c|c|c|c|}
\hline & $\begin{array}{c}\text { Dorsal } \\
\text { eyes }\end{array}$ & $\begin{array}{c}\text { Eyes } \\
\text { without } \\
\text { halos }\end{array}$ & $\begin{array}{l}\text { Extrabulbar } \\
\text { seminal } \\
\text { vesicle }\end{array}$ & $\begin{array}{l}\text { Paired } \\
\text { seminal } \\
\text { vesicle }\end{array}$ & $\begin{array}{l}\text { Female atrium only } \\
\text { partially occupied by } \\
\text { the multilayered lining }\end{array}$ \\
\hline G. beckeri Froehlich, 1959 & + & $?$ & + & + & + \\
\hline G. caapora Froehlich, 1958 & + & - & + & + & - \\
\hline G. carrierei Graff, 1897 & + & - & + & + & - \\
\hline G. chiuna E. M. Froehlich, 1955 & + & + & - & + & + \\
\hline G. crawfordi de Beauchamp, 1939 & + & + & - & + & + \\
\hline G. crioula E. M. Froehlich, 1955 & + & - & + & + & - \\
\hline G. fragai Froehlich, 1955 & - & + & - & - & + \\
\hline G. gaucha Froehlich, 1959 & + & - & + & + & - \\
\hline G. goettei Schirch, 1929 & - & + & + & - & + \\
\hline G. incognita Riester, 1938 & + & + & + & - & + \\
\hline G. josefi sp. nov. & + & + & + & + & + \\
\hline G. matuta Froehlich, 1955 & - & + & - & + & + \\
\hline G. mirim E. M. Froehlich, 1972 & + & - & + & + & + \\
\hline G. multicolor Graff, 1899 & + & - & + & + & - \\
\hline G. phocaica Marcus, 1951 & - & + & + & - & + \\
\hline G. placilla E. M. Froehlich, 1978 & + & - & + & - & + \\
\hline G. preta Riester, 1938 & - & + & + & - & + \\
\hline $\begin{array}{l}\text { G. saima du Bois-Reymond Marcus, } \\
1951\end{array}$ & - & + & + & - & + \\
\hline G. suva Froehlich, 1959 & - & + & + & - & + \\
\hline G. tapira Froehlich, 1958 & + & + & + & - & + \\
\hline G. tuхаиа E. M. Froehlich, 1955 & - & + & - & + & + \\
\hline $\begin{array}{l}\text { G. vaginuloides Prudhoe } \\
\text { (not Darwin), } 1949\end{array}$ & + & + & - & - & - \\
\hline
\end{tabular}

+: present; -: absent; ?: not clear. 
Most species with a multilayered lining in the female atrium present an extrabulbar seminal vesicle (Table 3), but only seven of them have forked proximal portions, similar to G. josefi: G. beckeri, G. caapora, G. carrierei, G. crioula, G. gaucha, G. mirim and G. multicolor. However, the relative length of the paired and unpaired extrabulbar portions in these species is very different when compared to that of G. josefi, wherein it is restricted to the proximities of the penis bulb.

As in G. polyophthalma Graff 1899 (Froehlich, 1956), incompletely mature worms of $G$. josefi have the forked portions of the vesicle relatively shorter than in mature specimens.

Regarding the height of the multilayered lining of the female atrium, as in most species (Table 3), in G. josefi this structure does not occupy most of the atrial cavity leaving a considerable part of

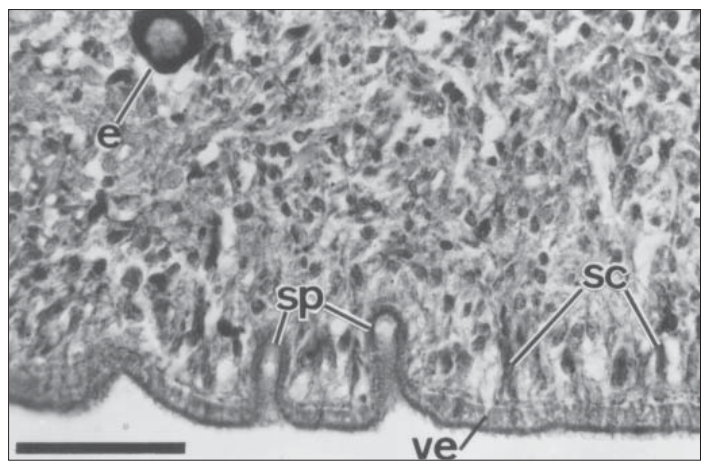

Fig. 11 - Sensory pits of holotype in a sagittal section. Scale bar: $50 \mu \mathrm{m}$. e = one-cup eyes; sc = secretory cells; $\mathrm{sp}=$ sensory pits; $\mathrm{ve}=$ ventral epidermis.

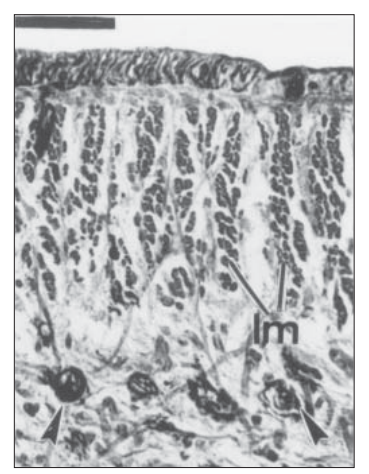

Fig. 13 - Dorsal part of a transverse section of the prepharyngeal region (paratype 312B) next to the margin of the body. Arrowheads show rhabditogen cells. Scale bar: 50 $\mu \mathrm{m} .1 \mathrm{~m}=$ longitudinal cutaneous muscles. the atrial lumen free. The morphology of this lining differs in $G$. josefi in presenting numerous indentations.

The allopatric Geoplana trigueira E. M. Froehlich, 1955 from the State of Rio de Janeiro shows a similar colour pattern to that of mature specimens of $G$. josefi and some aspects of the anatomy of its copulatory organs are also coincident. Its seminal vesicle is, however, unpaired and retorta-shaped and the female atrium does not possess a multilayered lining (Froehlich, 1955a).

For $G$. josefi the following statement by E. M. Froehlich (1955b), referring to the colour development during sexual maturation of the geoplanids, is not applicable: "Nem sempre a existência do segundo orifício [gonóporo] indica maturidade completa, mas nesta altura já se acha presente o colorido definitivo".

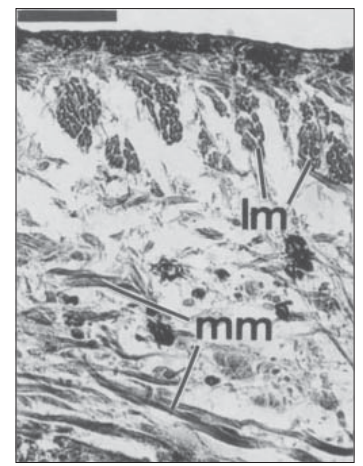

Fig. 12 - Dorsal median part of a transverse section of the pre-pharyngeal region (paratype 312B). Scale bar: 50 $\mu \mathrm{m} .1 \mathrm{~m}=$ longitudinal cutaneous muscles; $\mathrm{mm}=$ mesenchymal muscles.

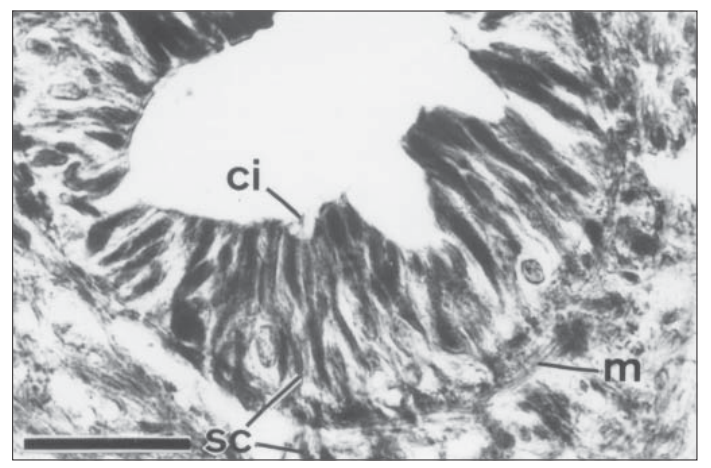

Fig. 14 - Detail of the paired extrabulbar portion of the seminal vesicle (holotype) in a sagittal section. Scale bar: $25 \mu \mathrm{m}$. ci $=$ cilia $; \mathrm{m}=$ muscles; $\mathrm{sc}=$ scretory cells. 


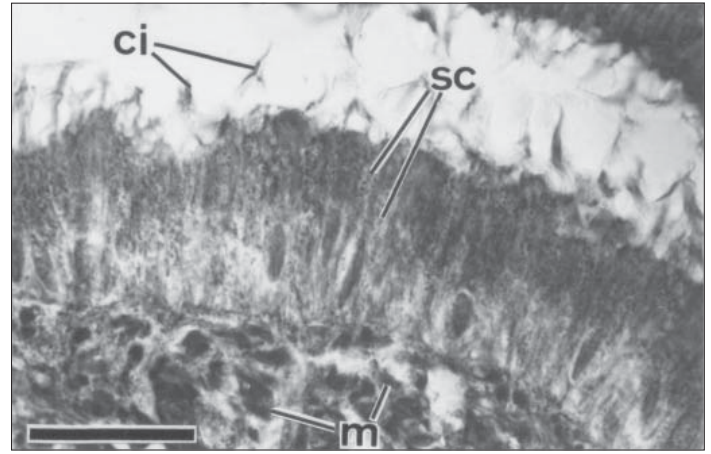

Fig. 15 - Detail of the unpaired intrabulbar portion of the seminal vesicle (paratype 312B) in a sagittal section. Scale bar: $25 \mu \mathrm{m}$. ci $=$ cilia $; \mathrm{m}=$ muscles; $\mathrm{sc}=$ secretory cells.

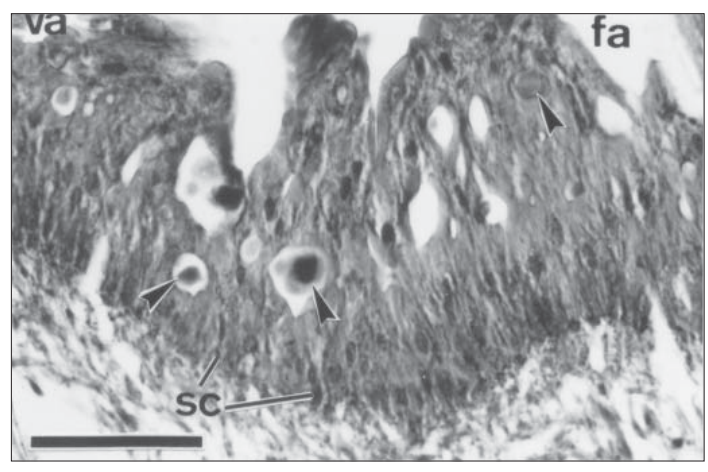

Fig. 16 - Sagittal section of the vagina and the female atrium (holotype) showing its multilayered epithelium. Arrowheads indicate granular secretion. Scale bar: $50 \mu \mathrm{m}$. $\mathrm{fa}=$ female atrium; $\mathrm{sc}=$ secretory cells; va = vagina

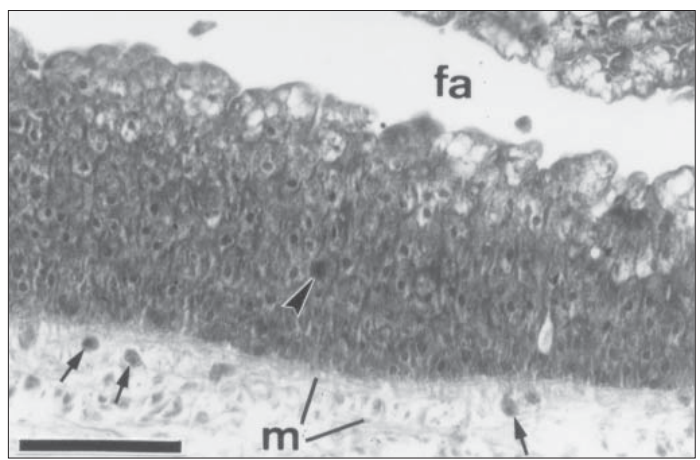

Fig. 17 - Horizontal section of the female atrium (paratype 585A) showing its multilayered epithelium. Arrows indicate cell bodies of acidophilic secretory cells; arrowhead indicates a granular secretion. Scale bar: $100 \mu \mathrm{m}$. fa $=$ female atrium; $\mathrm{m}=$ muscles.

The paratypes n. 485, 453, 229 and 255 each have a gonopore, but do not yet show the characteristic colour pattern of the mature worms.

Acknowledgments — The authors are grateful to Prof. Dr. Eudóxia Froehlich for the comments and suggestions made on an early draft of this paper and to Mr. Ramon Arthur Clark for the revision of the english text. Thanks are also due to Ms. Jaqueline Rodrigues and Ms. Letícia Ayres Guterres for their help with the histological technique, and Mrs. Teresinha Hensel de Oliveira for assistance with the photography.

\section{REFERENCES}

FROEHLICH, C. G., 1955, Sobre morfologia e taxonomia das Geoplanidae. Bol. Fac. Fil. Ciênc., Sér. Zool., 19: 195-279.

FROEHLICH, C. G., 1956, Planárias terrestres do Paraná. Dusenia, 7(4): 173-196.

FROEHLICH, C. G., 1959, On geoplanids from Brazil. Bol. Fac. Fil. Ciênc., Sér. Zool., 22: 201-265.
FROEHLICH, E. M., 1955a, Sobre espécies brasileiras do gênero Geoplana. Bol. Fac. Fil. Ciênc. Letr., Sér. Zool., 19: 289-369.

FROEHLICH, E. M., 1955b, Chave para a classificação das geoplanas brasileiras. Pap. Avul. Dpto. Zool., 8: 201-214.

GRAFF, L. V., 1899, Monographie der Turbellarien. II. Tricladida Terricola. Engelmann, Leipzig, 574p.

LEAL-ZANCHET, A. M. \& CARBAYO, F., 2001, Two new species of Geoplanidae (Platyhelminthes, Tricladida, Terricola) from Brazil. J. Zool, 253: 433-446.

OGREN, R. E. \& KAWAKATSU, M., 1990, Index to the species of the family Geoplanidae (Turbellaria, Tricladida, Terricola) Part I: Geoplaninae. Bull. Fuji Women's Coll., 28(2): 79-166.

ROMEIS, B., 1989, Mikroskopische Technik. Urban und Schwarzenberg, München, 697p.

WINSOR, L., 1998, Aspects of taxonomy and functional histology in terrestrial flatworms (Tricladida: Terricola). Pedobiologia, 42: 412-432. 